\title{
Impact of Training on Employees Performance and Job Satisfaction: An Empirical Study of Plastic Industry of Hayatabad Industrial Estate
}

\author{
KHALIQ RAZA \\ MS Scholar, CECOS University of IT and Emerging Sciences, Peshawar
}

DR. FAHAD KHAN AFRIDI

CECOS University of IT and Emerging Sciences, Peshawar

Fafridi449@gmail.com

SYED IMRAN KHAN

Lecturer, Institute of Business Studies and Leadership

Abdul Wali Khan University, Mardan

syedzadaimran@awkum.edu.pk

\begin{abstract}
In today era of knowledge economy where organizations excel due to its human capital in order to provide quality product and service. The human capital can only be effective if organizations provide effective trainings to its employees regularly and need basis. Such training leads to not only over all organization's development but it affects the job satisfaction and performance of employees. The research purposes are to know about the title of the research which is conducted about Plastic Industry of Hayatabad, District Peshawar. A total of 184 middle and lower managers were selected for the study through proportionate stratification sampling technique. Five point Likert scales, adopted and used by several researchers, were utilized for the research study. The results of study found that employee's training has a major significant impact on employee performance and job satisfaction. The results also revealed that training has a positive correlation among the two variables. The research study recommended several recommendations such as provision of on the job and of the job trainings through systematic training program, establishment of a training center, linking trainings with the strategic plan of the firms.
\end{abstract}

Keywords: Knowledge Economy, Human Capital, Training, organization's Deveopment, Job Satisfaction

\section{Introduction}

In today era of knowledge economy where organizations excel due to its human capital in order to provide quality product and service. The human capital can only be effective if organizations provide effective trainings to its employees regularly and need basis. Such training leads to not only over all organization's development but it affects the job satisfaction and performance of workforces. According to (Wesley \& Skip) states that training program improved very helpful in the organization because it provide quality 
customer services and consistency in both job performance and satisfaction but also increase employee's commitment with the organization.

According to (Conrade \& Woods, 1994; Wesley\&Skip, 1999) usually researchers agree to take a decision that training increases and improves both employees' job satisfaction and length of employment in the organization. It is pointed out by the past research that training have an impact on the following organization dimensions i.e. employee quality service, employee turnover rate and also organization performance. In Pakistani context research studies has been conducted (Amin, 2013) however, their domain were telecommunication or banking sectors. Furthermore, the literature is deficient in to determine the impact of training on job satisfaction and employee performance in plastic firms of Hayatabad Industrial Estate Peshawar. Besides, as for as the China Pakistan Economic Corridor and strategic importance of Khyber Pakhtunkhuwa are concerned, in terms of Human Capital for required mega projects, it is a unique study to fill the gap in the available literature. The present study aims to focus on Plastic Manufacturing industry of Industrial Estate Hayatabad, located in District Peshawar. It further aims to analyze the impact of training, specifically provided to middle and lower managers, on employees' level of job satisfaction and their performance.

\subsection{Research Questions}

- Has training an impact on employee performance?

- Has training an impact on job satisfaction of employee?

\subsection{Research Objectives}

2. To determine the impact of training on employees' performance

3. To figure out the impact of training on employees' job satisfaction

\subsection{Significance of the Research}

In the back drop of CPEC where accumulation of Human Capital is indispensible for Khyber Pakhtunkhuwa this research would provide a guideline for the Industry and in broader sense to the Government for focusing on training for better employee's performance and job satisfaction. The research study adds to the existing knowledge through enhancing the literature on the subject matter which can provide knowledge to the students of Human Resource Management. Furthermore, it helps the researcher community by provided relevant data for future researchers. Last but not least the present study is addressing a practical problem of the industry of the province by providing a researchable solution.

Normally, all the employees in the organization are encouraged by good leader, working environment, peers and members are mostly inspired by the work obligation, satisfaction and job performance. According to the earlier research studies that the training activities have an important role in the during work of employees obligation/commitment, job satisfaction and performance. Training are based on the following four dimensions 1.training commitment 2.training need assessment 3.training guts/subjects and distribution methods 4.training assessment that bore on the employee's work commitment, satisfaction and job performance. This study judges that how to understanding impact of training on duty of workers in organization, commitment, job satisfaction and performance therefore it is key phase in solving the problem of 
employee's assigning duty, satisfaction and performance. According to the literature viewed that there numbers of factor which effect on the employee's work, commitment Such as employee's emotions and strength (Allen and Mayer, 1990). The main purpose of the training practice that how to create level of employee's commitment, performance and job satisfaction in the organization in order to satisfy with their job tasks and others works tasks and others

\section{Literature Review 2.1. Training}

Several authors have describes training in their own ways. In the words of Tharenou, Saks and Moore (2007:252) defined as "an organized achievement and increase of the human capital are essential for workforces to effectively done a work or to develop performance in the employee working condition". While some are of the view that it focuses education members of the organizations, how they can perform their tasks through gathering knowledge and attaining skills (Jones, George and Hill, 2000). Training is defined as a practice through which human capital regarding the job is provided (Blanchard \& Thacker, 2013). Employees if provided with skills, education and knowledge inculcate the sense of job satisfaction. Badillo-Amador and Villaa (2013) found that training when provided improperly leads to dissatisfaction of employees as the desired skills and job description are not aligned. Training has a lot of benefits for both organization and employees in the form of improvement in performance of employees, productivity of the organization and quality (Aguinis \& Kraiger, 2009). Researchers found that for high performance in the industry organization should deeply focus on the training (Werner \& DeSimone, 2012). The now-a-days tendencies in HRM practices all over the world are changing vigorously. Currently, companies are varied about their employee's retention, turnover and cost cut off; therefore it is necessary for the employers that they taken interest in the employee's improvement due to training practice for that purpose to retain organization employees and also encouraged. It is studied that due to training practices employee's motivation is increased as well as employee's performance and organization's performance.

According to Michael Jucius (1955) for the accomplishment of a certain task/job it is necessary that employee have good abilities, knowledge and work expertise and for the fulfillment of these conditions proper training should be provided to the employees in the organization. Dale S. Beach (1980) defines that training is a set of practice due to training activities employee increase their knowledge, skills and abilities for the achievement of a particular aims and objectives. Dubashi, P.R (1983), states "It is the method or practice by which the organization can get their objectives through employee's improved human capital. It is an important for every organization that they provide clean and suitable work environment that they used their knowledge, skills and abilities through professional course of training in the organization. Stephen P. Robins and David A. Decenzo (1989) explain that "training is a process through employee gain knowledge and information an the basis of work experience and their attitudes and behavior are also change by employee's knowledge and know how with work in which it looks for a reasonably endless change in employee that they will promote his or her 
capability to perform the job". Noe. Raymond (2010) defines Training as a proposed strength with appropriate arrangement to develop a continuous progress of employee's awareness, skills and abilities that are correlated to his/her job. According to Sultana et al. (2012) studied that there are different sectors of Pakistan such as telecommunication which is a part of training practice and the effect of training program on the employee's performance has been identified.. In this research mixture of questionnaire surveys and literature review are included. It is necessary for every organization that provided preplanned systemic training for the performance improvement and also productivity as well as goals and objectives. Training is not considered only for business life but also must for daily routine activities in life. It is just like an asset of the business in Human Resource. Every organization has a choice to select a method of training on the bases of training issue which is occurred in the organization. Training has a dynamic role because it joining the gap for both knowledge and skills which is necessary for the job. It has been studied that test, mistake and observation the employee can not improve their knowledge skills and abilities but through prearranged and systematic training, employees learn their job. It means that training is playing an important role in the knowledge economy.

The aim of the training is to increase an employee's knowledge and skills, change in the behavior and attitude according to the jobs need and request for learning skills no the behalf of routine work. This is must for every organization /employer that they basic training to the employee for improvement of knowledge, skill and ability.

According to the research that is has been identified employee development and performance have significant role if a proper training must be given them in the organization but it is clear that the entire performance of the organization depends upon the employee's effectiveness. The study found that employee performance can only be improved if specific training may be provided. Besides training could be a best tool to assess the market.

\subsection{Organizational Support for Training}

Organizational support is imperative for providing training. It is the responsibility of the organization to help its employees to receive training. For this organizations should establish a friendly atmosphere of continuous training and motivate its employees to get training. To support this argument, Cortini (2016) states that those organizations which encourage its employees to receive training by offering some compensations or rewards eventually establish organizational support for training.

\subsection{Training Opportunity}

It is significant for the organizations to inculcate the sense of new idea development. This can only be possible if training opportunities may be provided by the Human Resource Development of an organization in order to equip them for creativity (McGuire, 2014). However, provision of opportunity is not that much easy as it is expecting in several organizations. For example, Lindsay, Canduela, and Raeside (2013) found that lower level managers are less willing to participate in the training programs.

\subsection{Theoretical Framework of Employee Training}

Two main theoretical approaches for training are Human Capital approach (Production and Consumption system) and technology based approach. The HCA states that training is an asset in human capital, hence, training can only be delivered to 
employees when earning from productivity is higher than cost incurred on training (Luo, 2000). Contrastingly, technology based approach entails training is a source of skill creation.

\subsection{Employee Performance}

Research studies found that employees with high satisfaction have high degree of job performance, resultantly retained to the organization and vice versa (Landy, 1985). Furthermore, less satisfied employees did not perform well due to lack of motivation. It became easy for the management of organizations to motivate their employees for high performance to success in the goals of the organization (Kinicki \& Kreitner, 2007).

\subsection{Training and Employee Performance}

There are some factors in the real world which is affected the organizational growth and expansion. The present study of the research shows that performance improvement and productivity enhancement depends upon the vital role of training during the development of organization. Training opportunities provide a best position to organization and will keep it on top struggle. By the research study it is identified that there is a major difference between trained employee nether untrained organization workforces. The present study point out that training is an instrument which acts a main role in making bridge between the recent level of performance and expected level of performance. Particular research studies have go on by looking at routine in terms of employee performance in particular (Purcell, Kinnie \& Hutchinson 2003; Harrison 2000) while others have prolonged to a general viewpoint of organizational performance (Guest 1997; Swart et al. 2005). There is a connection/link a among accuracy, thoroughness, productivity and goal attainment when the employee's performance increased than the organization performance will also be increased, it means that there is a direct relationship between employee's quality of functions and organization.

On the bases of above relation, Wright and Geroy (2001) suggest that employee abilities and learning, advancement, skill building and career planning through effective training programs. Training program not only develops the loyalty, reliability and flexibility but all particular actions, deeds and proceeding of the employees to efficiently perform their career but also improve their education of the workers which is required for the upcoming job, thus contributing to artistic and dramatic production of the organization. Wright and Geroy (2001), states that employee knowledge, skills and abilities are change through effective training programs. The research study identified that training program not only increases the overall performance of the employees to effectively perform the current job but also enhance the employees competencies which are essential for the future job, thus contributing to higher organizational structure , methodology and unity also. Through training the employee knowledge economy are improved and allow them to apply the career related work efficiently, and achieve firm objectives in a economical and economical way. But on the other hand, dissatisfaction complaints, absenteeism and turnover can be greatly reduced when workforce is well trained that can know-how the direct satisfaction which are connected with the sense of success/accomplishment and knowledge that they are increasing their fundamental or intrinsic capabilities (Pigors \& Myers 1989).

\subsection{Training and Job Satisfaction}

\section{H1: Training has a significant impact on employee performance}


According to (Young 2000) the basic concepts of HRM about the literature for employee's retaining and progress of the human capital to expedite/enable them for a competitive advantage. The main issue in the managing of labor turnover has become a growing challenge particularly in professional organizations like in health and academic institutions (Cappelli 2000). The employee's instability, additional work load and stress will be result of employee turnover and absenteeism but on another side remaining staff thus escalating job dissatisfaction which causes the turnover cycle (Moseley et al. 2008). Schuler and Jackson (2006) also defines that hiring employees to meet the organization's human resource demands is only half of what is needed in talent management. The requirement to retain these people is another combat/battle. All those Organizations that have lower labor turnover rates increase/gain a competitive advantage through a decrease in overall labor costs and an rise in productivity. According to Horwitz (2008) skills shortages are a threat to economic growth. He argues that employee's retention strategies are serious in a global market that is faced with the shortage human capital and knowledge economy. South African is not the part of skills shortage but also the developing countries are also facing these challenges. Therefor it is important for both business, government public and private sector leaders to make special arrangement for conducting training program in the organization that increase employee's retention and decrease turnover and absenteeism etc. Moseley et al. (2008) state that employee retention is playing a vital role in the employee performance and thus increases the organization productivity but instability, additional work load bad working environment as a result of turnover but as well as stress on remaining staff, increasing job dissatisfaction and therefore causing/producing the turnover cycle.

H2: Training has a significant impact on employee job satisfaction

\section{Theoretical Frame work}

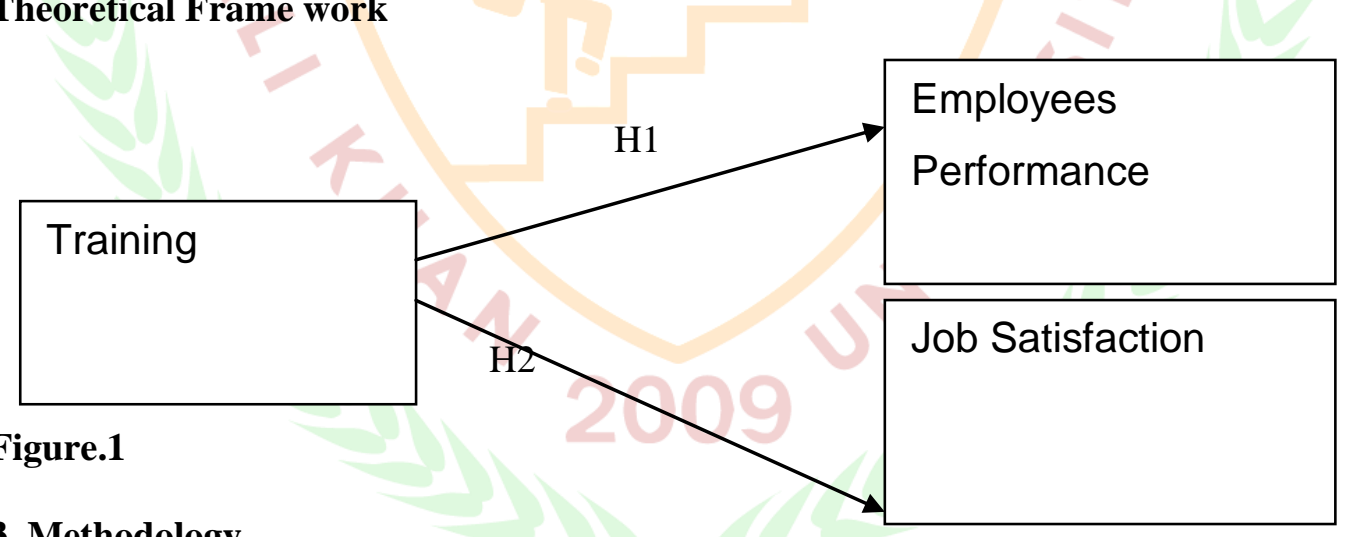

\section{Methodology}

In this chapter the research methodology of the research study has been described. It comprised of different sections such as research approach, methodological choice, population and sample information, variable information and overall research design of the study.

\subsection{Research approach}

The research approach used is deductive.

\subsection{Methodological choice}

Quantitative technique has been used for the research study. 


\subsubsection{Population}

The population of research consists of all the middle and lower employees of total 20 plastic manufacturing firms of Industrial Estate Hayatabad Peshawar. Out of these 20 firms 7 firms are not listed corporations hence the left over 14 firms that are listed have been taken for the present research study. Total 937 employees of different levels are working in these 14 listed plastic manufacturing firms. Out of these employees, 184 are middle and lower managers working in different categories.

\subsubsection{Sample}

Sample size is 126 which are determined through using the formula Yamane (1967) of finite population.

Rent

\section{(Figure.2)}

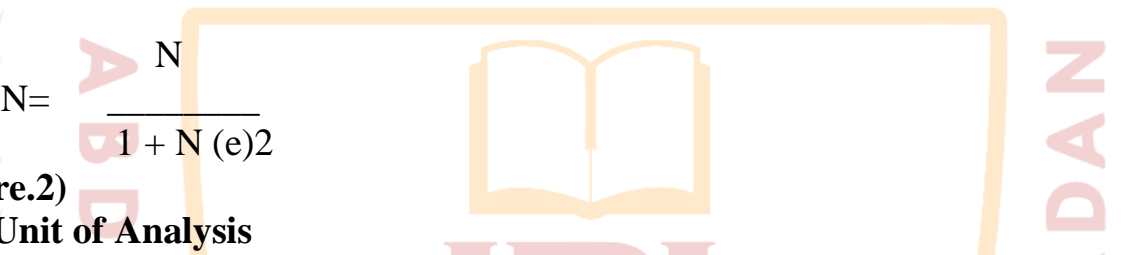

\subsubsection{Unit of Analysis}

The unit of analysis would be the managers who receive trainings on regular basis.

\subsubsection{Sampling Technique:}

A proportionate stratification has been used in order to get the data from those who are the true representatives of population, i.e, middle and lower level managers.

\subsubsection{Research Instrument}

The research instruments for measuring the three variables of Training, Employees' Performance and Job satisfaction had been adopted from the past researchers i.e, Zumrah (2015), Antoncic \& Antoncic (2011) and Taylor \& Bowers (1974). The responses were gathered on 5 points likert scales. Moreover a total of 126 questionnaires were distributed among the respondents out of which 102 questionnaires were returned properly filled (41 from Middle and 61 from Lower Managers) the rest 24 questionnaires were not considered and discarded due to improper filling and incomplete returns. The questionnaires were personally distributed by the researcher acted as enumerator and the respondents were guide and explained all the questions. The survey took almost two months to complete the survey.

\section{Independent Variable Training}

Training is the independent variable of the current study. It has been measured through five point likert scale from (1) Strongly Disagree to (5) Strongly Agree, adopted from Curry et, al (1997) which was used by Zumrah (2015). The total items of the scale used were 4 , with 0.84 reliability.

\section{Dependent Variables}

\section{Employee performance}

Employee performance being the dependent variable was measured through 5 point likert scale used by Antoncic \& Antoncic (2011) with reliability of 0.71 .

\section{Job Satisfaction}

Job satisfaction has been measured through five point likert scale, designed by Taylor and Bowers (1974) with 0.71 reliability. The total items of the scale are 7 


\section{Results and Discussion}

\subsection{Analysi}

Simple Regression analysis has been used for the present research study using SPSS 2.0 version.

\subsection{Population}

The target population consisted all of the middle and lower employees of total 20 plastic manufacturing firms of Industrial Estate, Hayatabad, Peshawar, Khyber Pakhtunkhwa.

1. Out of those 20 firms 7 firms were not listed corporations thereby the leftover 14 firms that were listed firms were considered for the study.

2. A total of 184 middle and lower level managers along with other employees were found working in those 14 listed plastic manufacturing firms. As the study focused on middle and lower level managers thereby the target population represented 184 analysis units.

\subsection{Sample Size and Sampling Technique}

Sample size was determined using sample size formula (Yamane, 1967) below:

Where

$$
\mathrm{n}=\mathrm{N} / 1+\mathrm{N}(\mathrm{e}) 2
$$

- $\mathrm{n}$ denoted sample size

- $\mathrm{N}$ represented target population

- e stood for precision level

Thus by putting values in the formula we obtained the desired sample size mentioned below;

$$
\begin{gathered}
\mathrm{n}=\mathrm{N} / 1+\mathrm{N}(\mathrm{e}) 2 \\
\mathrm{n}=184 / 1+184(0.05) 2 \\
\mathrm{n}=126
\end{gathered}
$$

\subsection{Sampling Technique}

A stratified simple random sampling technique was used to obtain the desired sample size of 126 middle manager and lower managers in equal proportions of $44 \%$ and $56 \%$ respectively. That was done in order to segregate the target population of 184 managers into i.e. Middle Managers and Lower Managers first and then to obtain stratified random samples and so the sampling units included $55(44 \%)$ middle managers and $71(56 \%)$ lower managers.

As the stratified random sampling included random sampling and simple random sampling is also known as probability sampling. Thereby sampling procedures must meet at least four criteria (Chochran1977:9), mentioned below;

- Linearity of residuals (The mean of the responses, $\mu_{Y}$, is a Linear function of the $x_{i}$ ).

- Independence of residuals (The errors, $\mathcal{E}_{\boldsymbol{i}}$, and hence the responses $Y_{i}$, are Independent.).

- Normal distribution of residuals (The errors, ${ }^{\mathcal{E}_{\boldsymbol{i}}}$, and hence the responses $Y_{i}$, are Normally distributed). 
- Equal variance of residuals (The errors, $\varepsilon_{i}$, and hence the responses $Y_{i}$, have Equal variances (denoted $\sigma^{2}$ ) for all $x$ values).

According to first assumption in linearity we draw a scatter plot of residuals and $y$ values. Y values are taken on the vertical y axis, and standardized residuals (SPSS calls them ZRESID) are then plotted on the horizontal $\mathrm{x}$ axis. If the scatter plot follows a linear pattern (i.e. not a curvilinear pattern) that shows that linearitv assumntion is met. The
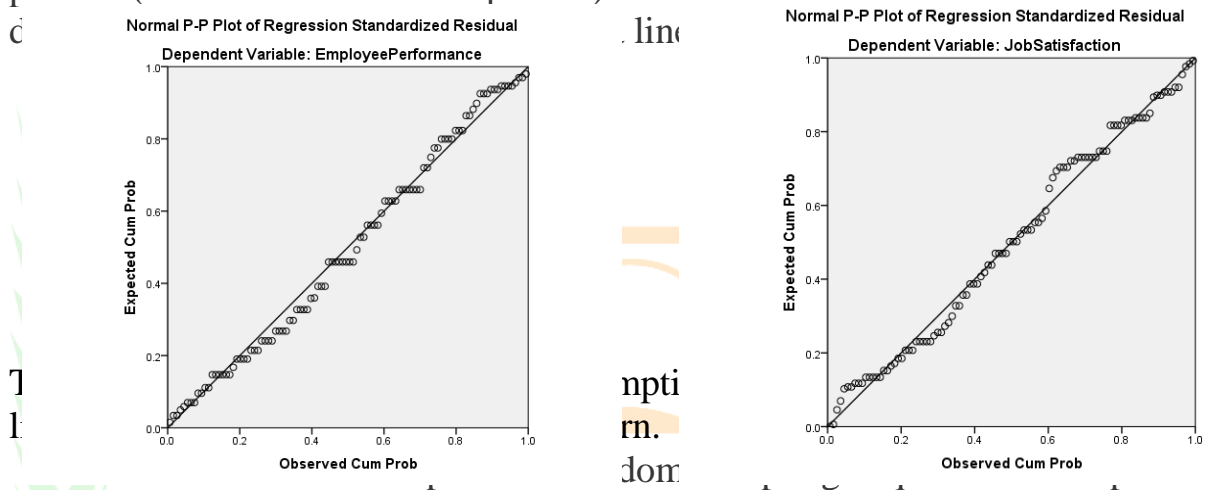

wed a

dom

ld be

independent and requires attention mostly in longitudinal datasets not cross sectional data sets and longitudinal data sets are the vice versa of cross sectional data sets. Thus out cross sectional datasets are those where we collect data only once. Thus this assumption was not applicable in our study.

The third assumption required, an examination of data already collected, and analyze the normality of the residuals. If the residuals are not to be skewed that would mean the assumption is satisfied.

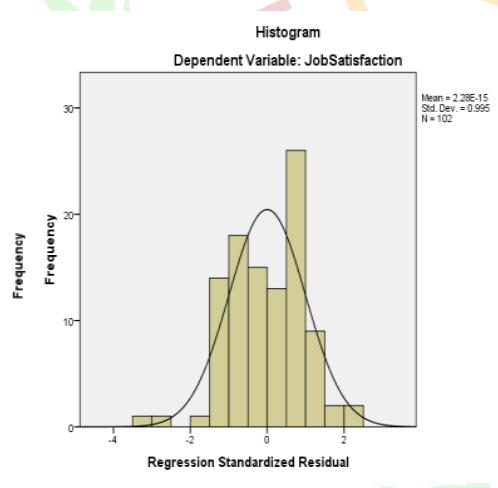

(Figure.6)

(Figure.5)

The above figure showed the data was not skewed and thus the third assumption was also satisfied. The fourth assumption required that both linearity and equal variance assumptions are satisfied.
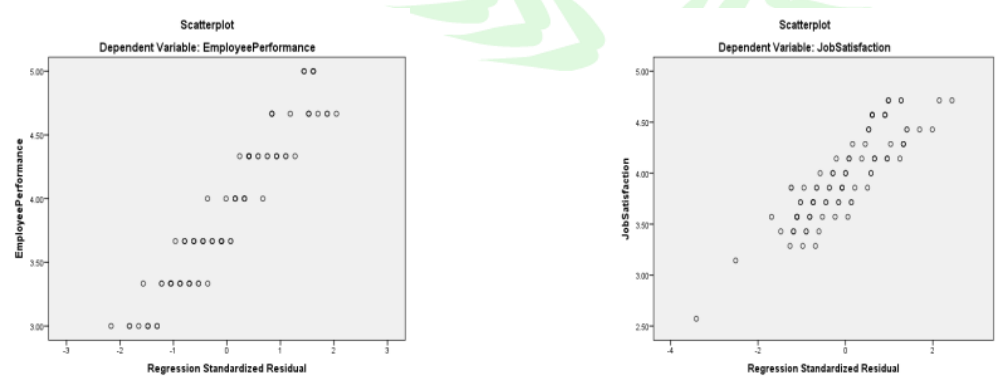

(Figure.7)

(Figure.8) 
Above figure shows the fourth assumption is satisfied.

\subsection{Regression Analysis}

The regression analysis may be defined as it is the relationship between the anticipated value of dependent variable and independent variable is called regression analysis. When the dependence of a variable on a single independent variable it is called a simple or two- variable regression. Likewise the dependence is represented by a straight line equation that is called linear regression.

In our regression analysis we assumed that the linear relationship between the dependent variable $\mathrm{Yi}$ and the value $\mathrm{Xi}$ of the repressor $\mathrm{X}$ is

And in terms of sample data as

$$
\mathrm{Yi}=\alpha+\beta \mathrm{Xi}+\varepsilon \mathrm{i}
$$

Whereas the estimated regression is written as

$$
\mathrm{Yi}=\mathrm{a}+\mathrm{bXi}+\mathrm{ei}
$$

$$
\mathrm{Yi}=\mathrm{a}+\mathrm{bXi}
$$

Where the Xi's are fixed or predetermined values,

The Yi's are observations randomly drawn from a population,

The $\varepsilon i$ 's are error components or random deviations,

$\alpha$ and $\beta$ are population parameters, $\alpha$ is the intercept and the slope $\beta$ is called regression coefficient, which may be positive or negative depending upon the direction between $\mathrm{X}$ and $\mathrm{Y}$.

Furthermore, we assume that

(i) $\mathrm{E}($ (ci) $=0$, i.e. the expected value of error term is zero, it implies that the expected value of $\mathrm{Y}$ is related to $\mathrm{X}$ in the population by a straight line;

(ii) $\operatorname{Var}(\varepsilon i)=E(\varepsilon i)=\sigma 2$ for all i, i.e. the variance of error terms is constant. It means that th distribution of erro has the same variance for all values of $\mathrm{X}$ (Homoscedasticity assumption).

(iii) $E(\varepsilon i, \varepsilon j)=0$ for $i \neq j$, i.e. error terms are independent of each other (assumption of no serial or auto correlation between $\varepsilon$ 's);

(iv) $\mathrm{E}(\mathrm{X}, \varepsilon \mathrm{i})=0$, i.e. $\mathrm{X}$ and $\varepsilon \mathrm{i}$ are also independent of each other;

(v) Ei's are normally distributed with a mean of zero and a constant variance $\sigma 2$. This implies that $\mathrm{Y}$ values are also normally distributed. The distributions of $\mathrm{Y}$ and $\varepsilon$ are identical except that they have different means.

According to the above regression model, each $\mathrm{Yi}$ is an observation from a normal distribution with mean $=\alpha+\beta \mathrm{X}$ and variance $=\sigma 2$.

Job training is predictor and the employee performance and the jobs satisfaction are the dependent variables.

\begin{tabular}{lllll}
\multicolumn{4}{c}{ Table 1: Model Summaries } \\
\hline Model & $\mathrm{R}$ & $R^{2}$ & Adjusted $R^{2}$ & $\begin{array}{l}\text { Std. Error of the } \\
\text { Estimate }\end{array}$ \\
\cline { 2 - 5 } & $0.313^{\mathrm{a}}$ & 0.098 & 0.089 & 0.55440
\end{tabular}

a. Predictors:

(Constant), 
Training

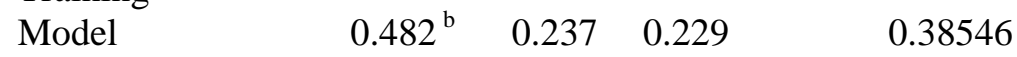

\section{a. Predictors:}

(Constant),

Training

Model summary (Figure1.7) provides $\mathrm{R}$ and $R^{2}$ values. The $\mathrm{R}$ values show correlation i.e. 0.313 and 0.482 which indicates a degree of positive correlation between the dependent and independent variables. The $R^{2}$ value indicates how much of the total variation in the dependent variables, Employee Performance and Job Satisfaction, can be explained by the independent variable, Training. In the above case, 0.098 and 0.237 is explained which show degree of positive correlations between the predictor and the dependent variables.

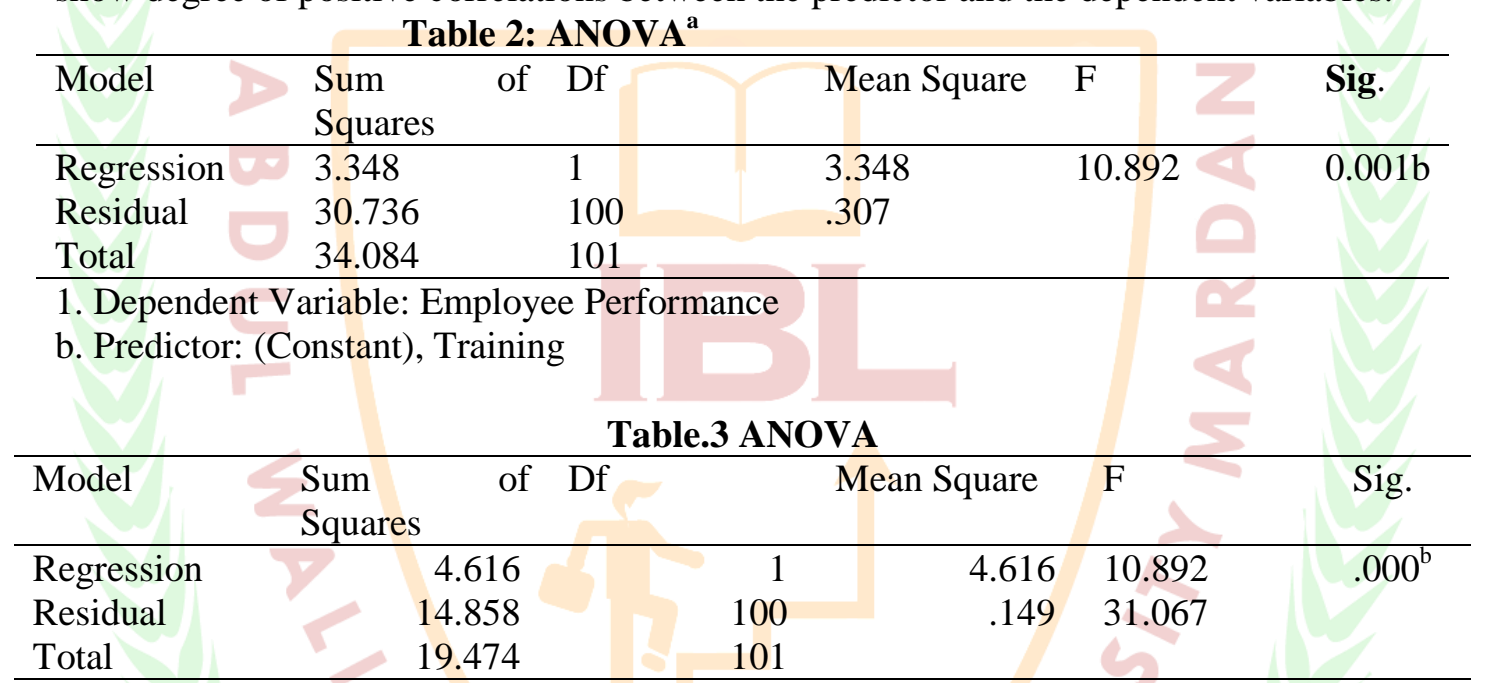

1. Dependent Variable: Employee Performance

b. Predictor: (Constant), Training

ANOVA table indicates how well the regression equation fits the data (i.e. predicts the dependent variable) and the regression model predicts the dependent variable, Employee Performance and Job Satisfaction, significantly well. With $p<0.001$ and $p<0.000$ which is less than 0.05 , indicates that, overall, the regression model significantly predicts the outcome variable. The findings are in lined with the past researches of Waris, A. P. M. d. A. (2015) and Kunartinah (2010).

The coefficients table, below, provides necessary information to predict Employee Performance and Job Satisfaction from the Training, as well as determine whether Training contributes statistically, significantly, to the model through the Sig. level as shown below:

Table 4. Coefficients

\begin{tabular}{|c|c|c|c|c|c|}
\hline \multirow[t]{2}{*}{ Model } & \multicolumn{2}{|c|}{$\begin{array}{l}\text { Unstandardized } \\
\text { Coefficients }\end{array}$} & $\begin{array}{l}\text { Standardized } \\
\text { Coefficients }\end{array}$ & $\mathrm{T}$ & Sig. \\
\hline & B & $\begin{array}{l}\text { Std. } \\
\text { Error }\end{array}$ & Beta & & \\
\hline (Constant) & 2.387 & .463 & & 5.149 & .000 \\
\hline
\end{tabular}


a. Dependent Variable: Employee Performance .001

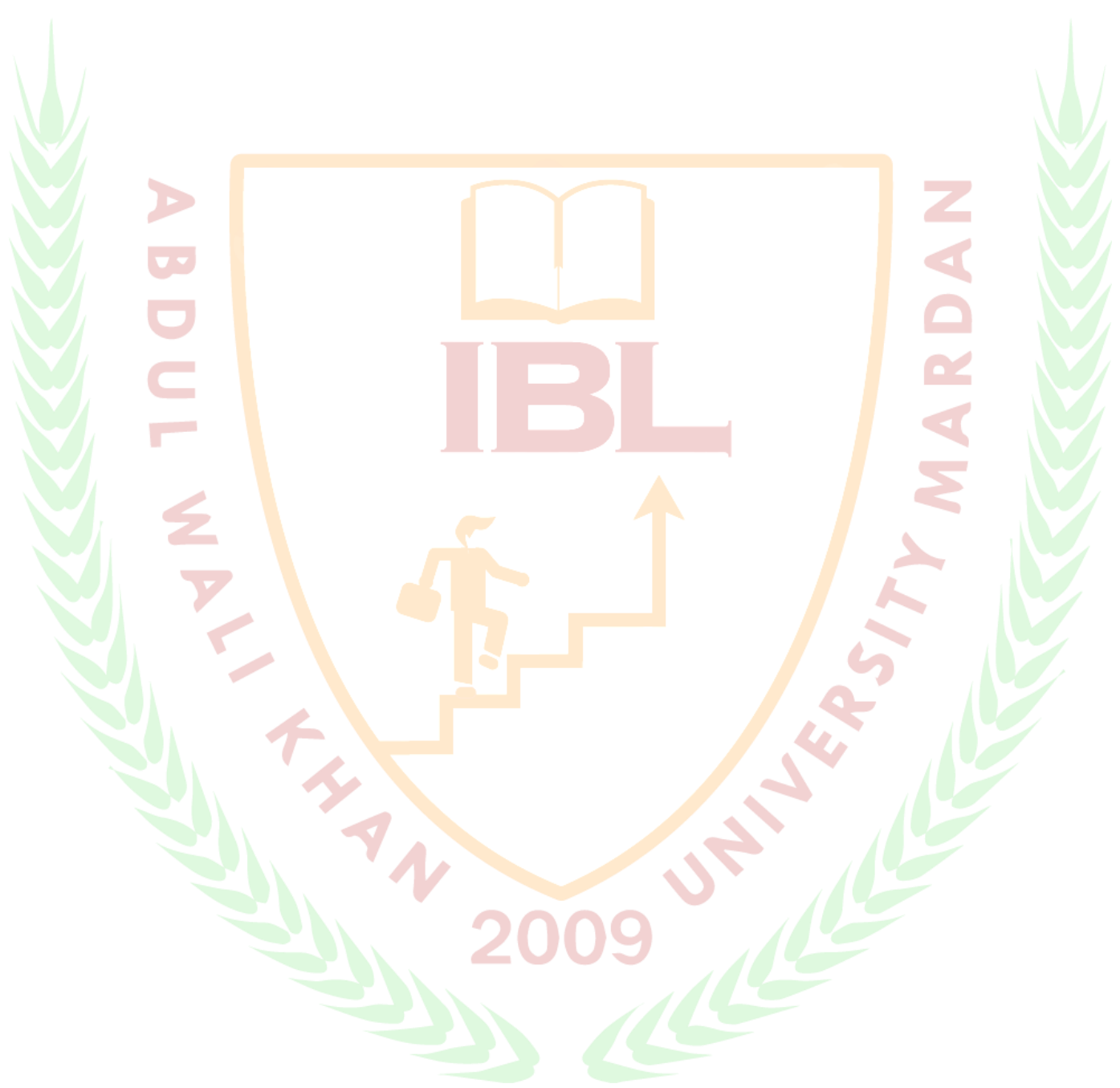


Table. 5: Coefficients

\begin{tabular}{|c|c|c|c|c|c|}
\hline \multirow[t]{2}{*}{ Model } & \multicolumn{2}{|c|}{$\begin{array}{l}\text { Unstandardized } \\
\text { Coefficients }\end{array}$} & $\begin{array}{l}\text { Standardized } \\
\text { Coefficients }\end{array}$ & $\mathrm{t}$ & Sig. \\
\hline & B & $\begin{array}{l}\text { Std. } \\
\text { Error }\end{array}$ & Beta & & \\
\hline (Constant) & 2.204 & .322 & & 6.840 & .000 \\
\hline Training & .449 & .080 & .487 & 5.574 & .000 \\
\hline
\end{tabular}

a. Dependent Variable: Job Satisfaction

Our regression equation mentioned earlier;

$$
\mathrm{Yi}=\mathrm{a}+\mathrm{bXi}
$$

And by putting values we got

$$
\begin{gathered}
\text { Employee Performance }=2.2387+0.328 \text { Training } \\
\text { and } \\
\text { Job Satisfaction }=2.204+.449 \text { Training }
\end{gathered}
$$

Where $\mathrm{b}(0.328)$ indicates the change in Yi (Employee Performance) for a one-unit change in X (Training) and similarly a (.449) change in (Job Satisfaction) is explained for a unit change in Training.

\section{Recommendations and Conclusion \\ 5.1 Recommendations}

- As training leads to enhanced job satisfaction and job performance hence a systematic training program should be introduced by the management of the Plastic firms for during the job and after job Trainings. Such training programs must be aligned to the strategic plans of the Plastic firms. Although the trainings have been provided already however, a systematic training program will help to assess the need of the training in specified areas.

- Job Rotation being a part of the Training should be add into the policy in the organization and consistent Job rotations shall be made and the employees be rotated from one job to another job in the same area of interest.

- Training should be according to the desired area of interest and the relevant field. For this

- Training Need Assessment Surveys should be conducted. This would help the management of the firms to provide need based training to the managers where it deemed require. Here, responsibility also lies on the supervisor incase of training to workers and higher management when training is provided to middle and lower management that what sort of training are necessary for the employees.

- Per Unit Production Efficiency (PUPE) of employees can be increased as a part of improving the Employee Performance if the desired trainings are delivered. For this a mechanism may be developed to assess the PUPE in a regular course of time.

- Pre and Post Training Assessment Surveys should be conducted to assess the trainees' level of understanding. In this regard the existing Standard Operating Procedures should be amended by inculcating the requirement of Pre and Post Training surveys. 
- Employee Job Satisfaction can become a part of Employee Job Retention and thus it requires specialized trainers to help them realize their potential and get motivated and remain more satisfied. Besides, the findings of the current study also suggests that skill through training leads to job satisfaction hence, training should be more focused in future in order to achieve higher level of satisfaction.

- Those employees who go through rigorous trainings then need to train their subordinates in the same fields as this would help them gain hands on experience in considerable less time as compared to those trainers having less practice and more theoretical knowledge.

- Every organization should either hire a group of consultants for training or establish their own formal training centers i.e, Capacity Building Centers or Center for Training and Capacity Building, for conducting trainings on regular basis. Such centers would regularly design trainings for the employees. Moreover, the performance of these centers should be linked to the strategic plan of the firms.

- Industries should focus more on hiring young business graduates with advanced qualifications as they may become assets after getting trained and getting more experience.

- Females should be given more opportunities in terms of hiring and there should be quota reserved for females during appointments that are made by the industrial sector.

- Human Resource Planning be done by the HR Departments of the industrial sector in order to forecast the human resource requirements in the coming decade. As in the next decade those employees having 44-55 age brackets would become obsolete and may drain organizational resources by taking away their rich experiences.

\subsection{Conclusion}

It is investigated by the research study that the basic aim is to identified the effect of training on job satisfaction and employee performance of plastic firms of Hayatabad Industrial Estate, district Peshawar. The study found that training has a significant positive impact on employee performance and job satisfaction. However, the study has several limitations i.e, respondents of plastic industries of Hayatabad Industrial Estate were considered. Besides, only quantitative technique was utilized. For future researches mixed method should be applied for more accurate results.

\subsection{Future Direction}

Apart from job satisfaction and employee performance, other variables should also be identified and considered for study that what impact training brings on such variables. Besides, other industries of Khyber Pakhtunkhuwa should also be involved in the scope of future study/research, especially in the light of CPEAC. Furthermore, research studies should also be conducted that how technology based Human Capital formation can be formed in order to operate in the Knowledge Economy of country. 


\section{Reference}

Aguinis, H. \& Kraiger, K. (2009). Benefits of training and development for individuals and teams, organizations, and society. Annual Review of Psychology, 60(1), 451474. Among lodging employees. Journal of Hospitality\& Tourism Research 23(2):176-94.

Anam A, Rashid S, Mr. R N L, Mizna, Simra, Anam I and Rida, T. (2013 )The Impact of Employees Training On the Job Performance in Education Sector of Pakistan . Middle-East Journal of Scientific Research 17 (9): 1273-1278, DOI: 10.5829/idosi.mejsr.2013.17.09.12289 and reality. Cornell Hotel \& Restaurant Administration Quarterly 35(5):16-21.

Antoncic, J.A. \& Antoncic, B. (2011). Employee Satisfaction, intrapreneurship \& firm growtha model. Industrial Management \& Data Systems. 111 (4), 589-607

Badillo-Amador, L., \& Vila, L. E. (2013). Education and skill mismatches: wage and job satisfaction consequences. International Journal of Manpower, 34(5), 416-428.

Blanchard, P. N., \& Thacker, W. (2013). Effective training: systems, strategies, and practices. Upper Saddle River, NJ: Pearson.

Cappelli, P (2000). A market driven approach to retaining talent. Harvard Business Review. 78(1): 103- 11

Conrade, G.,\&Woods, R. N. (1994). Training in the U.S. lodging industry: Perception

Cortini, M. (2016), Workplace identity as a mediator in the relationship between learning climate and job satisfaction during apprenticeship. Journal of Workplace Learning, 28(2), $54-65$.

De young P. (2000). High technical talent perks are ripe for picking. Journal of Work Span, 43(10): 283.

DeSimone, R. L., \& Werner, J. M., (2012). Human resource development. Mason, OH: Cengage Learning

Horwitz F 2008. Retention strategies critical in a global market skills shortage. Resource Management Journal, 13(4): 23-44 http://dx.doi.org/10.1108/JWL-06-2014-0048

Jones, G.R., George, J.M., and Hill, C.W.L. (2000), Contemporary Management, New York: Irwin and McGraw Hills.

Kinicki, A. and Kreitner, R. (2007), Organizational Behavior, McGraw-Hill, New York

Landy, F. W. (1985).The psychology of work behavior(3rd ed.). Homewood, IL: Dorsey Press.

Lindsay, C., Canduela, J., \& Raeside, R. (2013). Polarization in access to work-related training in Great Britain. Economic and Industrial Democracy. 34(2), 205-225.

Luo, X (June, 2000). The Rise of Personal Development Training in Organizations: A Historical and Institutional Perspective on Workplace Training Programs in the U.S.

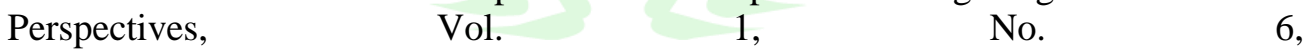
http://www.oycf.org/Perspectives2/6_063000/rise_of_personal_development_tra.ht $\mathrm{m}$

McGuire, D. (2014). Human resource development, London, UK: Sage Publications

Moseley A, Jeffers L, Patterson J 2008. The retention of the older nursing workforce: A literature review exploring factors that influence the retention and turnover of older nurses. Contemporary Nurse. Australian Nursing Profession, 30(1): 46-56 
Pigors, P. \& Myers, A. C. 1989. Personnel Administration, A point of view and method, 9th Ed. New York. McGraw Hill Book Company.

Schuler SR, Jackson SC 2006. Managing human resources. Cengage learning. Sociology. 66(1): 32- 40.

Tharenou, P., Saks, M.A. and Moore, C. (2007), A review and Critique of research on training and organizational-level outcomes, Human Resource Management Review (17): 251-273

Wesley, S. R., \& Skip, S. (1999). Training and its impact on organizational commitment Workplace Learning, Vol. 27 Iss 7 pp. 514 - 529 Permanent link to this document:

Wright, P. \& Geroy, D. G. 2001. Changing the mindset: the training myth and the need for word-class performance. International Journal of Human Resource Management $12,4,586-600$.

Yamane, T. (1967). Statistics, An Introductory Analysis, 2nd Ed., New York: Harper and Row.

Zumrah. R,A, (2015),"How to enhance the impact of training on service quality?", Journal of Workplace Learning, 27(7), pp: 514-529

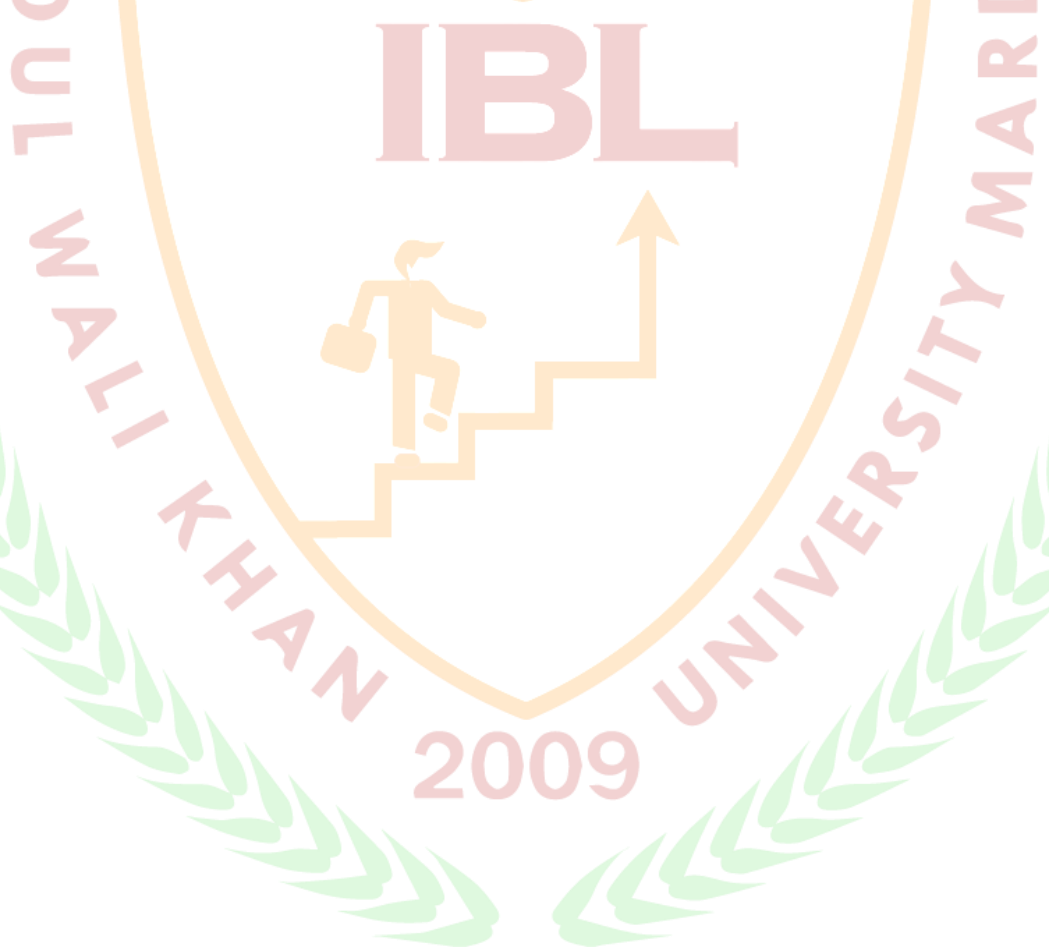




\section{Annexure \\ Questionnaires}

\section{Training}

1 Strongly Disagree-----5 Strongly Agree

As a result of the training,

(I) have substantially increased my knowledge on the topic.

(2) As a result of the training, I have developed new skills.

(3) The training has affected some of my attitudes concerning this topic area.

(4) As a result of the training, I have better conceptualization of what I already do on the job.

\section{Employee Performance}

1 Strongly Agree---------5 strongly disagree

1. I can complete a given task before the stipulated time, and accordance with the standard expected

2. I can adjust to changes and innovations that exist

3. I can work together with other employees, and meet commitments related to my job

\section{Job Satisfaction}

Taylor \& Bowers (1974)

( 1 completely satisfied, --------5= completely unsatisfied)

1. All in all, how satisfied are you with the persons in your work group

2. All in all, how satisfied are you with your supervisor

3. All in all, how satisfied are you with your job

4. All in all, how satisfied are you with this organization compared to most?

5. Considering your skills and the effort you put into your work, how satisfied are you with your pay?

6. How satisfied do you feel with the progress you have made in this organization up to now?

7. How satisfied do you feel with your chance for getting ahead in this organization in the future? 